\title{
Correspondence
}

\section{Is Hepatitis C Virus a Sialotropic Virus?}

\section{To the Editor-in-Chief:}

Sjögren's syndrome (SS) is an autoimmune disease that mainly affects the exocrine glands and usually presents as persistent dryness of the mouth and eyes due to functional impairment of the salivary and lachrymal glands. A possible relationship between SS and hepatitis C virus (HCV) was postulated in 1992 by Haddad et al, ${ }^{1}$ who reported the occurrence of characteristic SS histological changes in the salivary glands of patients with $\mathrm{HCV}$ infection. Various mechanisms may contribute to the pathogenesis of SS associated with HCV infection. These include a direct infection and proliferation of $\mathrm{HCV}$ in salivary glands, molecular mimicry between HCV and salivary glands, and formation of immune complexes containing HCV. A recent experimental murine model study has shown a direct link between HCV and SS. Koike et $\mathrm{al}^{2}$ described the development of an exocrinopathy resembling SS in the salivary and lachrymal glands of transgenic mice carrying the HCV envelope genes, and suggested that the envelope proteins of HCV may recruit lymphocytes in the salivary glands thus leading to the formation of lymphocytic infiltrates. However, Pawlotsky et al ${ }^{3}$ suggested that lymphocytic infiltration of salivary glands could be due to the presence of immune complex deposits in capillaries or to HCV replication in salivary glands or in lymphocytes infiltrating the glands.

Arrieta et $\mathrm{al}^{4}$ have reported that HCV infects and replicates in epithelial cells from salivary glands of patients with SS or chronic sialadenitis, suggesting that HCV shows a specific tropism for infecting exocrine glands. This represents the first pathological evidence in humans of a direct link between HCV infection and SS. Previously, several studies have shown the existence of sicca symptomatology, positive ocular tests, lymphocytic infiltration of salivary glands, and autoantibodies in patients with HCV infection. ${ }^{5}$ These findings may lead to a diagnosis of $\mathrm{SS}$ in some HCV-patients. We recently described the clinical and immunological features of 35 patients with $\mathrm{HCV}$ infection who fulfilled a minimum of four of the six European criteria for the classification of primary SS. ${ }^{6}$ Several studies $^{7,8}$ have suggested that HCV infection may account for the pathogenesis of a subgroup of patients with "primary" SS, especially in patients with evidence of liver involvement or associated cryoglobulinemia. Chronic HCV infection may remain subclinical for many years, and may be clinically expressed as the appearance of dryness of the mouth and eyes, and these HCV patients may be misdiagnosed as primary SS for a considerable period.

An interesting common feature of primary SS and HCV infection is the association with two specific conditions: mixed cryoglobulinemia (MC) and non-Hodgkin lymphoma (NHL). A strong association between $\mathrm{MC}$ and
$\mathrm{HCV}$ infection is recognized, while MC in SS has been associated with a high incidence of $\mathrm{HCV}$ infection. ${ }^{9}$ In addition, the main immunological feature in the $35 \mathrm{HCV}$ related SS patients in our above-mentioned study ${ }^{6}$ was cryoglobulinemia which was present in $60 \%$ of the patients. This further emphasizes the strong relationship between SS, HCV, and MC. The second condition associated with both diseases is $\mathrm{NHL}$, the most serious complication in the evolution of primary SS, ${ }^{10}$ which has also been recently described in patients with chronic HCV infection. ${ }^{11}$ We have described the development of $\mathrm{NHL}$ in two of our HCV-related SS patients (both with cryoglobulinemia), ${ }^{6}$ and Selva-O'Callaghan et $\mathrm{al}^{12}$ have described a patient with primary SS who was subsequently diagnosed as HCV positive and who finally developed $\mathrm{NHL}$. It is possible that the coincidence of HCV infection, $\mathrm{SS}$, and cryoglobulinemia in the same patient may favor the development of lymphoproliferative processes.

Is HCV a sialotropic virus? The data reported by Arrieta et $\mathrm{al}^{4}$ suggest that HCV may be a direct cause of sialadenitis in humans. Currently, HCV can be considered as a virus with a triple tissue tropism (hepatotropism, lymphotropism, and sialotropism), and this could explain a greater prevalence of sicca syndrome, cryoglobulinemia, and lymphoproliferation observed in patients with chronic $\mathrm{HCV}$ infection. However, the role of $\mathrm{HCV}$ and its viral proteins in the pathogenesis of SS is not clear at present.

\section{Manuel Ramos-Casals Mario Garcia-Carrasco Ricard Cervera Josep Font}

University of Barcelona Hospital Clinic

Barcelona, Spain

\section{References}

1. Haddad J, Deny P, Munz-Gotheil C, Ambrosini JC, Trinchet JC, Pateron D, Mal F, Callard P, Beaugrand M: Lymphocytic sialadenitis of Sjögren's syndrome associated with chronic hepatitis $C$ virus liver disease. Lancet 1992, 339:321-323

2. Koike K, Moriya K, Ishibashi K, Yotsuyanagi H, Shintani Y, Fujie H, Kurokawa K, Matsuura Y, Miyamura T: Sialadenitis histologically resembling Sjögren syndrome in mice transgenic for hepatitis $C$ virus envelope genes. Proc Natl Acad Sci USA 1997, 94:233-236

3. Pawlotsky JM, Roudot-Thoraval F, Simmonds P, Mellor J, Ben Yahia MB, Andre C, Voisin MC, Intrator L, Zafrani ES, Duval J, Dhumeaux D: Extrahepatic immunologic manifestations in chronic hepatitis $\mathrm{C}$ and hepatitis C virus serotypes. Ann Intern Med 1995, 122:169-173

4. Arrieta JJ, Rodriguez-Iñigo E, Ortiz-Movilla N, Bartolomé J, Pardo M, Manzarbeitia F, Oliva H, Macias DM, Carreño V: In situ detection of hepatitis C virus RNA in salivary glands. Am J Pathol 2001, 158:259264

5. Ramos-Casals M, García-Carrasco M, Cervera R, Font J: Sjögren's syndrome and hepatitis C virus. Clin Rheumatol 1999, 18:93-100

6. Ramos-Casals M, García-Carrasco M, Cervera R, Rosas J, Trejo O, de la Red G, Sánchez-Tapias JM, Font J, Ingelmo M: Hepatitis C virus infection mimicking primary Sjögren's syndrome: clinical and immunologic description of 35 cases. Medicine (Baltimore) 2001, 80:1-8 
7. García-Carrasco M, Ramos M, Cervera R, Font J, Vidal J, Munoz FJ, Miret C, Espinosa G, Ingelmo M: Hepatitis C virus infection in "primary" Sjögren's syndrome: prevalence and clinical significance in a series of 90 patients. Ann Rheum Dis 1997, 56:1-3

8. Jorgensen C, Legouffe MC, Perney P, Coste J, Tissot B, Segarra C, Bologna C, Bourrat L, Combe B, Blanc F, Sany J: Sicca syndrome associated with hepatitis C virus infection. Arthritis Rheum 1996, 39:1166-1171

9. Ramos-Casals, Cervera R, Yagüe J, Garcia-Carrasco M, Trejo O, Jiménez S, Morlá RM, Font J, Ingelmo M: Cryoglobulinemia in primary Sjögren's syndrome: prevalence and clinical characteristics in a series of 115 patients. Semin Arthritis Rheum 1998, 28:200-205
10. Ramos-Casals M, García-Carrasco M, Font J, Cervera R: Sjögren's syndrome and lymphoproliferative disease. Cancer and Autoimmunity. Edited by Shoenfeld Y, Gershwin ME. Amsterdam, Elsevier, 2000, pp 55-80

11. Pozzato G, Mazzaro C, Crobatto M, Modolo ML, Ceselli S, Mazzi G, Sulfaro S, Franzin F, Tulissi P, Moretti M: Low-grade malignant lymphoma, hepatitis C virus infection, and MC. Blood 1994, 84:30473053

12. Selva-O'Callaghan A, Rodriguez-Pardo D, Sanchez-Sitjes L, MatasPericas L, Solans-Laque R, Bosch-Gil JA, Vilardel-Tarres M: Hepatitis $C$ virus infection, Sjögren's syndrome, and non-Hodgkin's lymphoma. Arthritis Rheum 1999, 42:2489-2490 